\title{
Age estimation of skeletal remains: principal methods
}

\author{
This article was published in the following Dove Press journal: \\ Research and Reports in Forensic Medical Science \\ 5 February 2014 \\ Number of times this article has been viewed
}

\author{
Chiara Villa \\ Niels Lynnerup \\ Unit of Forensic Anthropology, \\ Department of Forensic Medicine, \\ University of Copenhagen, \\ Copenhagen, Denmark
}

Correspondence: Niels Lynnerup Unit of Forensic Anthropology, Department of Forensic Medicine, Frederik d 5's Vej II, DK-2I00

Copenhagen, Denmark

Tel +4535327239

Fax +453532 6150

Email nly@sund.ku.dk

\begin{abstract}
The age of an individual is often a fundamental piece of data in connection with forensic identification of unidentified bodies. The methods most often used are based on visually determining various morphological, age-related changes in the skeleton (or teeth, although odontological methods are not reviewed in this paper). As such, these methods are all relative: ie, they do not obtain results in calendar years but estimates of the age at death, often with a rather large range. Recently, methods have been proposed for more direct ascertainment of age at death: eg, protein racemization and radiocarbon methods. The latter method, especially, may yield absolute age (year of birth), because radiocarbon activity (as measured in specific proteins in specific cells or tissues of the body) may be in equilibrium with the so-called bomb-pulse, when atmospheric radiocarbon content has changed markedly from one year to another. This review covers the basic and most often used gross morphological methods, radiologically-based methods, biochemical methods, and radiocarbon dating.
\end{abstract}

Keywords: skeletal, aging, human remains

\section{Introduction and background}

Identification of human remains almost always involves assessment of the age at death of the individual. While aging phenomena occur in non-bony tissues, it was for a long time osseous tissue and teeth that were at the core of most methods. ${ }^{1-7}$ This was due both to the persistence of these tissues (when most soft tissues would decompose) and the fact that age determination is much-used also in archaeological work, when excavating prehistoric and historic skeletons. ${ }^{3,4}$ In forensic cases, determining age at death and year of birth are, in all practicality, two sides of the same issue. However, since many of the most-used methods were developed also for use in archaeological anthropology, they are usually referred to as methods for determining age at death. An archaeologically recovered individual can seldom be set in an absolute chronological framework (unless, for example, by tombstones, inscriptions on coffins, coffin plates, etc). But in forensic cases, determining age at death is often translated into probable year of birth (or a range for this), as this is an item of data that may be registered, and thus lead to identification.

A fundamental presupposition of most forensic anthropological methods is that the biological age of an individual more or less follows the chronological age. The chronological age is our calendar age, which we identify in years, while the biological age refers to how aging affects our bodies and how this may be observed. Generally, most age assessment methods rely on identifying certain age-related skeletal traits, then setting these traits in a system of stages or scores, which results in an estimated 
age interval..$^{2-7}$ However, more recently, methods that rely on biochemical analyses, as well as isotope, heavy metals, and radiocarbon analyses, have been introduced that are also applicable to other tissues (although most methods still focus on skeletal and dental tissues).

In this review, the conventional morphological methods used by the forensic anthropologist will be presented. Odontological methods will be addressed elsewhere.

\section{Methods relying on macroscopic morphological features}

Assessing age may be done somewhat reliably when dealing with subadults, as the biological-chronological relationship is clearly reflected in the growing subadult skeleton. Thus, features associated with bone growth, such as epiphyseal closure, ${ }^{4-7}$ closure of the sphenobasilar synchondrosis, ${ }^{5}$ and, obviously, (diaphyseal) bone length ${ }^{4,7-9}$ may be used.

Concerning the adult skeleton, most methods focus on the nonsynovial joints (synostoses and synchondroses), ie, joints between single bones, without a synovial membrane between (which also precludes any movement in the joint except for minor elastic bending), as seen, for example, in the sacrum and innominates. One of the first methods to be devised relies on cranial sutures. Described by Broca in 1875 , it has since been tested extensively - although, with the overall finding that, even though there seems to be an age-related trend in the complete ossification of the sutures (seen as obliteration), this trend is, perhaps, more tenuous than for the other methods described below. ${ }^{7,10-13}$ It has also been difficult to develop unbiased and definite criteria for using sutures in age determination. ${ }^{11-14}$ Several standards have been proposed for tabulating sutural ossification, including those of Acsadi and Nemeskeri ${ }^{15}$ (as incorporated in their Composite method), Buikstra and Ubelaker, ${ }^{3}$ and Meindl et al. ${ }^{12}$ The latter standard, especially, which also utilizes some minor sutures of the lateral aspect of the skull, is commonly used. One benefit of Meindl et al's method, aside from accuracy, is the documentation of the skull gained indirectly; assigning scores for ten sutural areas on the skull attests also to the preservation and completeness of the cranial vault. ${ }^{12}$ As such, this method is often recommended, although some studies seem to indicate that endocranial ossification might be more accurate than ectocranial ossification. Accessing endocranial sutures should not really be a problem in forensic cases, where the cranial vault is opened at autopsy anyway; so, this might be more strongly recommended. ${ }^{16}$ Aside from the major sutural systems of the vault, several researchers have also investigated other sutural systems, such as the frontosphenoidal sutures, ${ }^{17,18}$ frontonasal sutures, ${ }^{19}$ and sutures of the maxilla and palate..$^{20,21}$

The hip has nonsynovial joints between the sacrum and hip bones (innominates). The pubic symphysis especially has a long history in forensic anthropological aging. Todd first described a method in $1920 .^{22}$ Since, there have been several modifications, ${ }^{23}$ not least the introduction of a reference set of casts by Suchey et al, ${ }^{24}$ which has become more-or-less a standard for aging the pubic symphysis. Whichever method is used, the basis is the same: different stages (or phases) are described (or furnished as casts), and are stated to be equal to some age interval. The investigator compares the morphology of the pubic symphysis of a given case against these stages, then reads the equivalent age interval. The stages reflect the changing morphology of the surface, from a juvenile aspect, which looks to some extent like the epiphyseal surface of a long bone (billowing, undulating surface morphology, without rim phenomena), to a more aged look (disappearing billowing, replaced by more dense and less structured bone, pitting, and bone growth along the rim). However, the relative delicacy of the pubic bone, which often may be fragmented or destroyed, may make the method impossible to use.

Basically, the same methods (describing age-related phases or stages) are applied to the auricular surface (the joint surface of the hip bone where it articulates with the sacral bone), although this joint has a more complex ligamentary construction, with a fluid filled space. The method first described by Lovejoy et al, ${ }^{25}$ and since modified by Buckberry and Chamberlain, ${ }^{26}$ operates with rather detailed points systems for grading different features, which should limit some error.

A final nonsynovial joint is the sternal rib end, where the bone rib articulates with cartilage between the rib and the sternum. Initially, perhaps, a rather optimistic precision was given for this method by Işcan et al, ${ }^{27}$ which has not quite been substantiated, but the method does have (as for the pubic symphysis) the advantage of casts. ${ }^{28}$ In terms of forensic anthropology, there is further benefit in this joint being easily accessible at autopsy; the rib cage is usually opened anyway, so that recovery and maceration of the fourth rib end is easy, unlike the task of removing and macerating parts of the hip bones to access the pubis symphysis or auricular surface. The overall common denominator for these age assessments is that joint surfaces and changes have been tabulated and related to broad age categories, typically ranging over 10 years or more.

Synovial joints may also be used to evaluate age, in the sense that development of arthrosis may give an indication 
of age. While arthrosis is age-related clinically, it is also related to numerous other things, including genetic makeup, nutrition, and loading. ${ }^{29} \mathrm{~A}$ scoring system for the degree of lipping on vertebral margins was published by Stewart (cited in Ubelaker), ${ }^{4}$ but does not seem to be used generally. However, for the experienced investigator, seeing arthritic developments on joint surfaces will indicate older age, and this will probably form part of the final age assessment, to some extent. This may also explain, in part, why experienced investigators perform quite well when they are asked to rapidly assess the age of a skeleton without resorting to strictly following the methods described above: changes in nonsynovial joints and synovial joints form a "pattern", which translates to an age interval - see below for more discussion of this point. ${ }^{30}$

\section{Radiology}

Radiological assessment of age at death has been proposed, by quantifying degree of trabecular bone loss at the proximal epiphyseal ends of long bones (humerus and femur). First described on macerated bone, ${ }^{15}$ the method may also be used on soft tissue-covered bone. ${ }^{31}$ There may be forensic anthropological cases where the removal of soft tissue is not feasible or where a quick age determination may be useful in the beginning phases of an identification case (eg, mass graves, mass disasters), without first having to macerate the remains.

Several of the above-mentioned morphological methods have been studied more recently, as age indicators based on computed tomography (CT) scans, and 3D visualizations based on CT scanning. Not least, this is due to the increasingly common procedure of performing CT scanning before autopsy at forensic institutes. Generally, the first studies tried to compare $\mathrm{CT}$ scan images and/or 3D visualizations directly with the above-described phases (eg, scoring sterna rib end, ${ }^{32}$ suture closure, ${ }^{33}$ and pubic symphysis), ${ }^{34}$ while since, more work has been done to directly describe stages or phases, based on CT information. ${ }^{35,36}$ In the future, it may be expected that more methods will incorporate digital information from a CT scan, rather than just purely morphological, visual (reconstructed) data; only a few studies have measured trabecular structure changes, ${ }^{37,38}$ or quantified curvature in the symphysis pubic. ${ }^{39}$ Adjunct to the much wider application of CT is the noteworthy fact that this may also be a basis for much more reference data. Most often, methods for dealing with dry bone were developed for specific anatomical collections (eg, the Terry collection at the Smithsonian Institution), which means that the age composition of the particular collection may carry over to those methods (ie, age mimicry ${ }^{40}$ - see Reaching a final age estimate section). Also, the collections reflect bony changes in humans who lived more than a hundred years ago, which raises the question of whether they are completely applicable to modern forensic cases (see Reaching a final age estimate section). Having an up-to-date digital database with CT scans means that many methods may now be tested and new methods developed on this material.

As will be seen, many of the forensic anthropological methods for determining age have been around for some time - some more than a hundred years, albeit with modifications - and form part of the basic forensic anthropological toolbox. ${ }^{1-7}$ These methods generally rely on identifying certain age-related morphological skeletal traits, then setting these traits in a system of stages or scores, which results in an estimated age interval. There are some basic problems inherent in this methodological approach, one of which is whether a given morphological method is well enough defined or explained, so that it does not entail undue intraor interobserver error when it is applied (ie, there should be no major ambiguity in the assessment of morphological features). Since the results of a forensic anthropological analysis may be presented in court, it is important, obviously, that the degree of observer variation for a given method is quantified. Therefore, continued assessment of the validity of the method, including intra- and interobserver assessment, is important. ${ }^{1}$

\section{Microscopy}

In 1965, Kerley described a method for determining age at death by counting the secondary osteons, osteon fragments, non-Haversian canals, and the percentage of lamellar bone from the mid-shaft of the femur, tibia, and fibula. ${ }^{41}$ Other workers have since modified and changed the method. ${ }^{42-45}$ The assessment of microscopic features in cross sections of the femur (or other bones) is considered a well-established method, and several studies have investigated the effects of preservation, disease processes, ${ }^{46,47}$ and, for example, the importance of the sampling location on the bone (proximal or distal). ${ }^{48}$

\section{Chemical and molecular biological methods}

Macroscopic morphological methods will continue to be around for a long time, even given their lack of precision, simply because the investigator can readily apply these methods directly on human remains and rapidly obtain a "ballpark" age estimation. However, a benefit of more advanced forensic 
laboratories means that more recent chemical and molecular biological methods can be brought to bear. These methods rely on ascertaining chemical changes in various tissues and molecules.

All amino acids, except glycine, contain a chiral, or asymmetric, center at the $\alpha$-carbon atom; the resulting two enantiomers are called the L- and D-enantiomers. Proteins are synthesized exclusively from the L-enantiomers. Once a protein is synthesized the L-amino acid residues begin an in situ conversion to the D-enantiomer, and this racemization will eventually stop when an equilibrium is reached, at $50 \%$ of each enantiomer. However, this process is very slow; it would take hundreds or thousands of years to complete, depending on the amino acid residue, the sequence, temperature, etc. The progress of the racemization process of a given protein may thus be a measure of the time elapsed since the protein was synthesized, provided that new protein synthesis does not occur and the protein is metabolically stable. Already, in 1975 , it was shown that there is a relationship between the chronological age of an individual and the degree of amino acid racemization in collagen from dental tissue. ${ }^{49-51}$ Agedependent amino acid racemization also has been observed in proteins found in vertebral discs and the eye lens. ${ }^{52-55}$ In theory, the racemization process is not directly coupled to the aging of the individual, but is simply a process that depends on when proteins were first generated in the body.

Studies have been made in quantifying the decrease of crosslinks between collagen molecules in collagenous tissues. ${ }^{56}$ These covalent crosslinks seem to reflect growth processes, and slowly decrease in number, in turn forming various end-stage compounds, not all fully-known. While the overall process has been shown to occur in human bone and cartilage samples from birth to 80 years old, ${ }^{57}$ attempts to generate more precise, forensically useful age estimations have yielded estimated errors of around \pm 15 years. ${ }^{58}$

Another chemical reaction that has been the focus of some research (also because the accumulation of certain end products is thought to be carcinogenic) is the Maillard reaction (also known as "the browning reaction") or, more precisely, advanced glycation end products. ${ }^{56}$ The reaction was first described by Maillard in 1912 as a complex, non-enzymatic suite of reactions between free amino groups (amins, aminoacids, peptides, and proteins) and reducing sugars. That a yellowing/browning takes place in tissues with molecules with a long lifetime (in the case of collagen molecules, with a lifespan of $>200$ years), ${ }^{59}$ has been shown for structures like the Achilles tendon, intervertebral discs, skin collagen, and dental collagen, as well as hippocampal neurons. ${ }^{60}$ As usual, the problem rests in translating a proven, biological development (ie, accumulation of certain end products) into an age estimation scheme. Yellowing of teeth has been quantified by visual inspection, densitometer, and direct measurement of pentosidine. ${ }^{61}$ Incidentally, somewhat related to forensic cases, browning of the skin, as seen in corpses lying in bogs, is probably also due to Maillard reactions, probably through the polysaccharide sphagnan, which is found in the bog, combining with amino groups from the decaying body. ${ }^{62}$

Telomeres are structures at the ends of chromosomes. Presumably, their task is to assure correct replication at disjunction, and to ensure proper reading of DNA strands. It has been found that the length of telomeres decreases with age, presumably due to cell divisions - the more cell divisions, the shorter the telomere length - and, since the number of cell divisions increases with age, telomere length could be a proxy for age. ${ }^{56}$ Indeed, several studies have shown this, ${ }^{63-66}$ although telomere length is individual, and relies on genetic and environmental factors. The error given in studies is around \pm 10 years. ${ }^{64,65}$

While the above-mentioned biochemical methods may hold promise for more accurate age estimates, most trial studies seem to indicate errors that are on a par with the best morphological methods. This begs the question whether these methods, with their need for more advanced laboratory work, are worthwhile. Of course, there may be cases where morphological methods cannot be used, simply because the relevant structures are missing; hence, biochemical methods, which depend only on miniscule amounts of teeth or bone tissue, have their use. Still, one has to take into account that biochemical methods are reliant on biochemical reactions. This means that diagenetic influences (eg, temperature) play a part (morphological features are "frozen" at death but may undergo gross anatomical breakdown post mortem). In fact, many studies of biochemical methods indicate that results may be dependent on storage. For example, racemization continues post mortem; if the ambient temperature is high, this process (like all biological processes) is more rapid, which may affect readings of the degree of racemization and, hence, the resultant age estimate. ${ }^{67,68}$

\section{Radiocarbon}

An absolute method for the determination of age (birth year) uses ${ }^{14} \mathrm{C}$ (radiocarbon) analysis. The method exploits variation in atmospheric ${ }^{14} \mathrm{C}$ levels during the last 50 years to date the formation of crystallines of the lens. The concentration of ${ }^{14} \mathrm{C}$ in living tissues reflects the atmospheric ${ }^{14} \mathrm{C}$ content at the time of their growth, because cosmogenic ${ }^{14} \mathrm{C}$ in the atmosphere 
reacts with oxygen to form carbon dioxide, which is incorporated by plants before being ingested by animals, both ultimately ingested by humans. When built into tissues and cells that have only very minor turnover (eg, dental enamel), ${ }^{69}$ the level of ${ }^{14} \mathrm{C}$ will reflect the level of atmospheric ${ }^{14} \mathrm{C}$. The amount of ${ }^{14} \mathrm{C}$ in the atmosphere was almost constant until about 1955, when nuclear bomb testing caused it to rise dramatically. ${ }^{70}$ After the 1963 Partial Test Ban Treaty, ${ }^{14} \mathrm{C}$ concentration decreased rapidly, mainly because atmospheric ${ }^{14} \mathrm{C}$ had dissolved into the oceans. Radioactive decay (the half-life of ${ }^{14} \mathrm{C}$ is 5,730 years) is of minor importance. ${ }^{71}$ Since the change in concentration is significant, even on a yearly basis, very accurate dating is possible. ${ }^{72,73}$ Radiocarbon dating for estimating the time of birth has also been applied to other tissues and structures that have little or almost no turnover, including neurons of the brain, ${ }^{74}$ special proteins in eye lens fibres, termed crystallines, ${ }^{75}$ and also bone. ${ }^{76}$

\section{Reaching a final age estimate}

The overall precision for many of the above-mentioned methods is generally around \pm 10 years. It may be hypothesized that many conventional methods may never achieve a higher precision, simply because of the nature of trying to quantify what is a slow and continuous process of bone remodeling throughout life. As earlier noted, biochemical methods are influenced by diagenetic factors, and have an error rate much like that of the macroscopic, morphological methods. One way to completely bypass the chronological age-biological age conundrum, and the variability of chemical processes, would be to use a nonbiological marker. Such a marker could be the rate of decay of a radioactive isotope like ${ }^{14} \mathrm{C}$, which is not affected by biological processes. However, a nonbiological marker needs to fulfil three basic criteria: 1) it must be incorporated in biological tissues at a specific point in time (eg, around birth), 2) it must be isolated in the organism (so that it is not in continuous equilibrium with extraorganismal concentrations), and 3) one has to be able to calibrate the marker against chronologically-known events. More research on absolute dating methods, with a view to narrowing dating to single amino acids, or specific parts of the skeleton (eg, ear bones, petrosal bone $)^{77}$ may make this method more applicable in those cases where teeth were not preserved.

Another major problem in forensic anthropology, largely unaddressed, is how to integrate the results of several methods (eg, when performing age evaluation). In a typical forensic case, the anthropologist may use several methods for ascertaining age, each yielding a slightly different estimate. It is not mathematically or statistically satisfactory to simply calculate a mean, or designate the lowest and highest age for any of the methods and present this as a combined result. Although so-called combined/composite methods have been described before, they have relied on using specific methods in a specific setup. ${ }^{15,78}$ More recent research has pointed to improvements through using different mathematical and statistical models to better integrate results from various methods. ${ }^{79}$ Specifically, Boldsen et al have contributed to the aspect of combining various age estimates with transition analysis. ${ }^{40}$ The method has been applied and tested on several archaeological materials, and has (until now) incorporated assessment of cranial sutures, symphyseal, and auricular changes. Future research should try to integrate other aging methods (eg, wrist X-ray, dental assessment) in this format, with a view also to better assessing age of the living.

Finally, the existence of comparative skeletal collections is important, not least because access to larger samples may result in more data on age changes, which may provide better "coverage" of a given method. ${ }^{80}$ Ultimately, the development of new methods relies on such collections. Some collections have specific data, including age, sex, and other data (eg, disease status) recorded for each skeleton, while other collections are of a more ethnographical or archaeological nature, for which these data are not available. Future trends might well see such collections being made available over the Internet (eg, by high-resolution CT scanning of the skeletons to build virtual libraries), allowing researchers easier access. As such, visualization of bone morphology using CT scan, surface laser scan, etc, may help in making anthropological methods more uniform in their application, as visual definitions of stages of change may be disseminated digitally (in contrast to the current use of descriptive texts, 2-D, and casts). Finally, as noted above, pre-autopsy CT scanning is becoming more common in forensic pathology, potentially leading to building modern, up-to-date virtual collections, where morphological methods may be tested and calibrated.

\section{Disclosure}

The authors declare no conflicts of interest in this work.

\section{References}

1. Cunha E, Baccino E, Martrille L, et al. The problem of aging human remains and living individuals: a review. Forensic Sci Int. 2009; 193(1-3):1-13.

2. Mays S. The Archaeology of Human Bones. London: Routledge; 1998.

3. Buikstra JE, Ubelaker DH. Standards for Data Collection from Human Skeletal Remains. Arkansas Archaeological Survey Research Series 44. Detroit: Wayne State University Press; 1984. 
4. Ubelaker DH. Human Skeletal Remains: Excavation, Analysis, Interpretation. Chicago: Aldine; 1978.

5. Krogman WM, Iscan MY. The Human Skeleton in Forensic Medicine. Springfield: Charles C Thomas; 1986.

6. Stewart TD. Essentials of Forensic Anthropology, Especially as Developed in the United States. Springfield: Charles C Thomas; 1979.

7. Ferembach D, Schwidetzky I, Stoukal M. Recommendations for age and sex diagnoses of skeletons, "Workshop of European anthropologists". J Hum Evol. 1980;9:517-549.

8. Hoffmann JM. Age estimations from diaphyseal lengths: two months to twelve years. J Forensic Sci. 1979;24(2):461-469.

9. Scheuer L, Black S. Developmental Juvenile Osteology. New York: Imprint Academic; 2000.

10. Todd TW, Lyon DW. Cranial suture closure, its progress and age relationship. I. Adult males of white stock. Am J Phys Anthropol. 1924;7(3):325-384.

11. Perizonius WRK. Closing and Non-closing Sutures in 256 Crania of Known Age and Sex from Amsterdam (ad 1883-1909). J Hum Evol. 1984;13(2):201-216.

12. Meindl RS, Lovejoy CO. Ectocranial suture closure: a revised method for the determination of skeletal age at death based on the lateral-anterior sutures. Am J Phys Anthropol. 1985;68(1):57-66.

13. Key CA, Aiello LC, Molleson T. Cranial suture closure and its implications for age estimation. Int J Osteoarch. 1994;4(3):193-207.

14. Hauser G, Manzi G, Vienna A, De Stefano GF. Size and shape of human cranial sutures A new scoring method. Am J Anat. 1991;190(3): 231-244.

15. Acsadi G, Nemeskeri J. History of Human Lifespan and Mortality. Budapest: Academiai; 1970.

16. Galera V, Ubelaker DH, Hayek LA. Comparison of macroscopic cranial methods of age estimation applied to skeletons from the Terry Collection. J Forensic Sci. 1998;43(5):933-939.

17. Dorandeu A, Coulibaly B, Piercecchi-Marti MD, et al. Age-at-death estimation based on the study of frontosphenoidal sutures. Forensic Sci Int. 2008;177(1):47-51.

18. Dorandeu A, Lorin de la Grandmaison G, Coulibaly B, et al. Value of histologicval study in the fronto-sphenoidal suture for the age estimation at the time of death. Forensic Sci Int. 2009;191(1-3):64-69.

19. Alesbury HS, Ubelaker DH, Berstein R. Utility of the frontonasal suture for estimating age at death in human skeletal remains. J Forensic Sci. 2013;58(1):104-108.

20. Wehrbein H, Yildizhan F. The mid-palatal suture in young adults. A radiological-histological investigation. Eur J Orthod. 2001;23:105-114.

21. Sejrsen B, Kjaer I, Jakobsen J. The human incisal suture and premaxillary area studied on archaeologic material. Acta Odontol Scand. 1993;51(3):143-151

22. Todd TW. Age changes in the pubic bone. I. The male white pubis. Am J Phys Anthropol. 1920;3:285-334.

23. Katz D, Suchey JM. Age determination of the male os pubis. Am J Phys Anthropol. 1986;69(4):427-435.

24. Suchey JM, Wisely DV, Katz D. Instructional material accompanying models of the Suchey-Brooks system. Bellevue, CO: France Casting; 1988.

25. Lovejoy CO, Meindl RS, Pryzbeck TR, Mensforth RP. Chronological metamorphosis of the auricular surface of the ilium: A new method for the determination of adult skeletal age at death. Am J Phys Anthropol. 1985;68(1):15-28.

26. Buckberry JL, Chamberlain AT. Age estimation from the auricular surface of the ilium: a revised method. Am J Phys Anthropol. 2002;119(3):231-239.

27. Işcan MY, Loth SR, Wright RK. Metamorphosis at the sternal rib end: a new method to estimate age at death in white males. Am J Phys Anthropol. 1984;65(2):147-156.

28. Işcan MY, Loth SR. Wright TK. Casts of age phases from the sternal end of the rib for white males and females. Bellevue, CO: France Casting; 1993.
29. Sokolove J, Lepus CM. Role of inflammation in the pathogenesis of osteoarthritis: latest findings and interpretations. Ther Adv Musculoskelet Dis. 2013;5(2):77-94.

30. Milner GR, Boldsen JL. Transition analysis: a validation study with known-age modern American skeletons. Am J Phys Anthropol. 2012;148(1):98-110.

31. Lynnerup N, Thomsen I, Frøhlich B. A non-invasive method for age at death determination. Med Sci Law. 1990;30(4):317-320.

32. Dedouit F, Bindel S, Gainza D, et al. Application of the Iscan method to two- and three-dimensional imaging of the sternal end of the right fourth rib. J Forensic Sci. 2008;53(2):288-295.

33. Grabherr S, Cooper C, Ulrich-Bochsler S, et al. Estimation of sex and age of "virtual skeletons" - a feasibility study. Eur Radiol. 2009; 19:419-429.

34. Telmon N, Gaston A, Chemla P, Blanc A, Joffre F, Rouge D. Application of the Suchey-Brooks method to three-dimensional imaging of the pubic symphysis. J Forensic Sci. 2005;50(3):507-512.

35. Ferrant O, Rouge-Maillart C, Guittet L, et al. Age at death estimation of adult males using coxal bone and CT scan: a preliminary study. Forensic Sci Int. 2009;186(1-3):14-21.

36. Barrier P, Dedouit F, Braga J, et al. Age at death estimation using multislice computed tomography reconstructions of the posterior pelvis. J Forensic Sci. 2009;54(4):773-778.

37. Pasquier E, De Saint Martin Pernot L, Burdin V, et al. Determination of age at death: assessment of an algorithm of age prediction using numerical three-dimensional CT data from pubic bones. Am J Phys Anthropol. 1999;108(3):261-268.

38. Wade A, Nelson A, Garvin G, Holdsworth DW. Preliminary radiological assessment of age-related change in the trabecular structure of the human os pubis. J Forensic Sci. 2011;56(2):312-319.

39. Biwasaka H, Sato K, Aoki Y, et al. Three dimensional surface analyses of pubic symphyseal faces of contemporary Japanese reconstructed with 3D digitized scanner. Leg Med (Tokyo). 2013;15(5):264-268.

40. Boldsen JL, Milner GR, Konigsberg LW, Wood JW. Transition analysis: a new method for estimating age from skeletons. In: Hoppa R, Vaupel J, editors. Paleodemography: Age Distributions from Skeletal Samples. Cambridge, UK: Cambridge University Press; 2002:73-106.

41. Kerley ER. The microscopic determination of age in human bone. Am J Phys Anthropol. 1965;23(2):149-163.

42. Ahlqvist J, Damsten O. A modification of Kerley's method for the microscopic determination of age in human bone. J Forensic Sci. 1969;14(2):205-212.

43. Bouvier M, Ubelaker DH. A comparison of two methods for the microscopic determiantion of age at death. Am J Phys Anthropol. 1977;46(3):391-394.

44. Kerley ER, Ubelaker DH. Revisions in the microscopic method of estimating age at death in human cortical bone. Am J Phys Anthropol. 1978;49(4):545-546.

45. Ericksen MF. Histologic estimation of age at death using the anterior cortex of the femur. Am J Phys Anthropol. 1991;84(2):171-179.

46. Lazenby RA. Inherrent deficiencies in cortical bone microstructural age estimation techniques. Ossa. 1984;9-11:95-103.

47. Martin DL, Goodman AH, Armelagos GJ, Pfeiffer S. On the use of microstructural bone for age identification. Curr Anthropol. 1981;22(4):437-438.

48. Pfeiffer S, Lazenby R, Chiang J. Brief Communication: Cortical remodelling data are affected by sampling location. Am J Phys Anthropol. 1995;96:89-92.

49. Helfman PM, Bada JL. Aspartic acid racemization in tooth enamel from living humans. Proc Natl Acad Sci U S A. 1975;72(8):2891-2894.

50. Helfman PM, Bada JL. Aspartic acid racemization in dentine as a measure of ageing. Nature. 1976;262(5566):279-281.

51. Ohtani S, Yamamoto K. Age estimation using the racemization of amino acid in human dentin. J Forensic Sci. 1991;36(3):792-800.

52. Mörnstad H, Pfeiffer H, Teivens A. Estimation of dental age using HPLC-technique to determine the degree of aspartic acid racemization. J Forensic Sci. 1994;39(6):1425-1431. 
53. Ritz S, Schütz WH. Aspartic acid racemization in intervertebral discs as an aid to postmortem estimation of age at death. J Forensic Sci. 1993;38:633-640.

54. Ritz S, Turzynski A, Schütz HW. Estimation of age at death based on aspartic acid racemization in noncollagenous bone protein. Forensic Sci Int. 1994;69(2):149-159.

55. Masters PM, Bada JL, Zigler JS Jr. Aspartic acid racemization in the human lens during ageing and in cataract formation. Nature. 1977;268(5615):71-73.

56. Zapico S, Ubelaker DH. Applications of physiological bases of ageing to forensic sciences. Estimation of age-at-death. Ageing Res Rev. 2013;12(2):605-617.

57. Eyre DR, Dickson IR, Van Ness K. Collagen cross-linking in human bone and articular cartilage. Age-related changes in the content of mature hydroxypyridinium residues. Biochem J. 1988;252(2):495-500.

58. Martin de las Heras S, Valenzuela A, Villanueva E. Deoxypyridinoline crosslinks in human dentin and estimation of age. Int J Legal Med. 1999;112(4):222-226.

59. Bank RA, Bayliss MT, Lafeber FP, Maroudas A, Tekoppele JM. Ageing and zonal variation in post-translational modification of collagen in normal human articular cartilage. The age-related increase in nonenzymatic glycation affects biomechanical properties of cartilage. Biochem J. 1998;330(Pt 1):345-351.

60. Solheim T. A new method for dental age estimation in adults. Forensic Sci Int. 1993;59(2):137-147.

61. Martin de las Heras S, Valenzuela A, Bellini R, Salas C, Rubino M, Garcia JA. Objective measurement of dental color for age estimation by spectroradiometry. Forensic Sci Int. 2003;132:57-62.

62. Painter TJ. Lindow man, tollund man and other peat-bog bodies: The preservative and antimicrobial action of Sphagnan, a reactive glycuronogylcan with tanning and sequestering properties. Carbohydr Polym. 1991;15(2):123-142.

63. Butler MG, Tilburt J, DeVries A, et al. Comparison of chromosome telomere integrity in multiple tissues from subjects at different ages. Cancer Genet Cytogenet. 1998;105(2):138-144.

64. Tsuji A, Ishiko A, Takasaki T, Ikeda N. Estimating age of humans based on telomere shortening. Forensic Sci Int. 2002;126:197-199.

65. Takasaki T, Tsuji A, Ikeda N, Ohishi M, 2003. Age estimation in dental pulp DNA based on human telomere shortening. Int J Leg Med. 2003;117(4):232-234

66. Ren F, Li C, Xi H, Wen Y, Huang K. Estimation of human age according to telomere shortening in peripheral blood leukocytes of Tibetan. Am J Forensic Med Pathol. 2009;30(3):252-255.
67. Masters PM. Age at death determinations for autopsied remains based on aspartic acid racemization in tooth dentin: importance of postmortem conditions. Forensic Sci Int. 1986;32(3):179-184.

68. Carolan VA, Gardner ML, Lucy D, Pollard AM. Some considerations regarding the use of amino acid racemization in human dentine as an indicator of age at death. J Forensic Sci. 1997;42(1):10-16.

69. Spalding KL, Buchholz BA, Bergman LE, Druid H, Frisen J. Age written in teeth by nuclear tests. Nature. 2005;437(7057):333-334.

70. De Vries H. Atomic bomb effect: variation of radiocarbon in plants, shells, and snails in the past 4 years. Science. 1985;128(33): 250-251.

71. Levin I, Kromer B. The tropospheric $14 \mathrm{CO} 2$ level in midlatitudes of the Northern Hemisphere (1959-2003). Radiocarbon. 2004;46(3):1261-1272.

72. Goodsite ME, Rom W, Heinemeier J, et al. High-resolution AMS (super 14) $\mathrm{C}$ dating of post-bomb peat archives of atmospheric pollutants. Radiocarbon. 2001;43(2B):495-515.

73. Kueppers L, Southon J, Baer P, Harte J. Dead wood biomass and turnover time, measured by radiocarbon, along a subalpine elevation gradient. Oecologia. 2004;141(4):641-651.

74. Bhardwaj RD, Curtis MA, Spalding KL, et al. Neocortical neurogenesis in humans is restricted to development. Proc Natl Acad Sci U S A 2006;103(33):12564-12568.

75. Lynnerup N, Kjeldsen H, Heegaard S, Jacobsen C, Heinemeier J. Radiocarbon dating of the human eye lens crystallines reveal proteins without carbon turnover throughout life. PLoS One. 2008; 3(1):e1529.

76. Hedges RE, Clement JG, Thomas CD, O'Connell TC. Collagen turnover in the adult femoral mid-shaft: modeled from anthropogenic radiocarbon tracer measurements. Am J Phys Anthropol. 2007;133(2): $808-816$.

77. Jørkov ML, Heinemeier J, Lynnerup N. The petrous bone - a new sampling site for identifying early dietary patterns in stable isotopic studies. Am J Phys Anthropol. 2009;138(2):199-209.

78. Lovejoy CO, Meindl RS, Mensforth RP, Barton TJ. Multifactorial determination of skeletal age at death: a method and blind tests of its accuracy. Am J Phys Anthropol. 1985;68(1):1-14.

79. Milner GR, Wood JM, Boldsen J. Paleodemography. In: Katzenberg MA, Saunders SR, editors. Biological Anthropology of the Human Skeleton. New York: Wiley; 2000. pp. 467-498.

80. Konigsberg LW, Herrmann NP, Wescott DJ, Kimmerle EH. Estimation and evidence in forensic anthropology: age-at-death. $J$ Forensic Sci. 2008;53(3):541-557.
Research and Reports in Forensic Medical Science

\section{Publish your work in this journal}

Research and Reports in Forensic Medical Science is an international, peer-reviewed, open access journal publishing original research, reports, reviews and commentaries on all areas of forensic medical science. The manuscript management system is completely online and includes a

\section{Dovepress}

very quick and fair peer-review system. Visit http://www.dovepress.com/ testimonials.php to read real quotes from published authors. 